\title{
Gender balancing your seminar speakers
}

Vicky MacRae \& Helen Sang

(As told to Alison Williams.)

In October 2016, the journal Nature, focusing on women in science, published an article headed: "Women need to be seen and heard at conferences". The article talks of "the vicious circle of invisibility" where women aren't thought of "for a scientific opinion for the media, or to mentor aspiring young scientists". Nor, they continue, are women "apparently thought of when conference organizers put together lists of speakers to invite to meetings" (Nature, 2016).

This recipe sets out how the Roslin Institute at the University of Edinburgh, having identified this issue, is tackling it with surprising and interesting results. They agree with BiasWatchNeuro that:

The progress of science benefits from diverse voices and ideas. Conference panels that are diverse with respect to gender, race, ethnicity and national origin help advance this goal. Homogenous conference programs are generally not representing their field, missing out on important scientific findings (https://biaswatchneuro.com/about).
The Roslin Institute holds a weekly seminar compulsory attendance for all postgraduate students, and strongly recommended for all staff - inviting external speakers annually from across the range of scientific interests at the Institute within animal and biomedical/ veterinary sciences. Prior to their successful 2014 Athena SWAN submission for Silver, the proportion of women external speakers was typically between 15 and $20 \%$. The Institute's stated aim was to change the external speaker programme "to ensure gender balance in proportion to female staff, with the expectation that female speakers will now form at least 30\% of the annual programme" aiming for this to increase over time. The $30 \%$ has been reached and overtaken. A mere 18 months later, between January and December $2016,56 \%$ of the external seminar speakers and $44 \%$ of the hosts were women.

A gender balance of seminar speakers also supports Roslin Institute's strong mentoring programme. For example, after a recent EBRC (Easter Bush Research Consortium) Fellows Seminar the two seminar speakers - both BBSRC (Biotechnology \& Biological Sciences Research Council) Future Leader Fellows - 
stayed on to participate in and contribute to a career development workshop with the postdoc and PhD students. This more diverse set of seminar speakers is beneficial for Roslin's postgraduate students and for recently appointed group leaders because it introduces them to a wider range of potential role models.

\section{Ingredients}

- A departmental culture that is actively working for gender equality with supportive policies in place.

- $\quad$ An engaged Director.

- A wider University context where Athena SWAN is taken seriously.

- A financial context where funders, for example the Wellcome Foundation, and the Company of Biologists, expect "diversity in speakers in terms of geography, gender and age" (http:// www.biologists.com/grants/).

- A proactive programme team with 'a good plan'.

- A proactive programme committee.

- Unconscious bias (UB) training:

- Compulsory unconscious bias, and Equality and Diversity online training for the whole department.

- $\quad$ Face-to-face unconscious bias training for senior positions and new fellows.

\section{Method}

\section{Instructions for the programme team (1 woman, 1 man):}

1. Convene the planning committee (gender balanced) and ask everyone to put forward their suggestions for speakers. Names are written on sticky notes and put up on the wall.

2. Shake your heads sorrowfully at the low percentage (usually only $20-25 \%$ ) of women suggested.

3. Challenge the planning committee to think of another $10-30 \%$ of potential women speakers. This pushes them well beyond the usual suspects and they almost always come up with the names of women doing interesting and cutting-edge work. Each person then makes supporting arguments for the scientific research that their suggested speakers (men as well as women) are doing.

4. Create a shortlist from which you pick your external seminar speakers (and have a few left over to fill any gaps that might arise as the year progresses). Create a second list of prominent high-profile women speakers for national and international conferences you may be holding in the future. 
5. Pick the women first. The men can wait until a slot becomes available the following year.

6. Be ready to challenge colleagues who are worried about "losing the quality" of their seminar series by inviting so many women.

- $\quad$ Remind them of the recurring bias that women are not as likely as men to be 'brilliant' particularly in fields where top-level success is believed to depend on 'innate intellectual giftedness' (Leslie et al., 2015).

- $\quad$ Remind your colleague(s) about the outstanding research work presented in the seminar programme by women that they would otherwise have missed.

- $\quad$ Refer to the context within which they are protesting: funder support, Athena SWAN submissions, the Director's focus.

- $\quad$ Send them links to the many websites (see Cook's tips below) in which senior men refuse to serve on all-male panels, the statistical work that sets out why the odds that a panel would randomly be all-men are astronomical, and sites such as biaswatchneuro. org that publish unequal gender representation in international conferences - do they really want the department to figure in this?
- If all else fails, show them the card Female Conference Speaker Bingo: Because making excuses is way easier than making progress (Caperton, 2012) that you have been marking as they talk.

7. Look after your seminar speakers and attendees:

- Day: Always hold your seminar on the same day of the week so that everyone can plan round it.

- Time: Hold it at lunchtime this is within flexible working hours, and works well when invited speakers are local.

- $\quad$ Support: Offer your speakers (men as well as women) childcare or childcare expenses. Roslin allocates a budget of up to $£ 200$ for childcare costs per speaker.

8. The Institute has found that if a speaker has to cancel it is more likely to be a woman than a man, and is most likely to be due to family issues. If a gap appears, pick a woman first rather than a man to fill it. 


\section{Cook's tips}

Things can easily slip back, so having an engaged Director is an essential ingredient. Despite the Institute's Athena SWAN goal of $30 \%$ women external speakers, at first the seminar programme continued with its previous 15$20 \%$ average. The 'Bingo' phrases crept in, from women as well as men. When the programme team became aware of this, they asked the Director to intervene. This shifted the whole approach from passive to active, with the excellent results described in this recipe.

\section{Some senior men refuse to} serve on all-male panels. See:

http://www.

womensmediacenter.com/ shesource/

http://speakerdiversity. com/\#about

http://www.embo.org/sciencepolicy/women-in-science (Contains databases of female life scientists in Europe.)

https://biaswatchneuro.com/ http://www.feministe.us/blog/ http://www.academia-net.org/ (Contains a database of leading female scientists in Europe.)

\begin{tabular}{|c|c|c|c|c|}
\hline \multicolumn{5}{|c|}{ Female Conference Speaker Bingo } \\
\hline $\begin{array}{l}\text { Women just } \\
\text { aren't } \\
\text { interested in } \\
\text { this field }\end{array}$ & $\begin{array}{c}\text { There aren't } \\
\text { enough } \\
\text { qualified female } \\
\text { speakers }\end{array}$ & $\begin{array}{c}\text { We need big- } \\
\text { name speakers, } \\
\text { and few of } \\
\text { those are } \\
\text { women }\end{array}$ & $\begin{array}{l}\text { It's a male- } \\
\text { dominated } \\
\quad \text { field }\end{array}$ & $\begin{array}{l}\text { There aren't } \\
\text { a lot of } \\
\text { women in } \\
\text { C-level } \\
\text { positions }\end{array}$ \\
\hline $\begin{array}{l}\text { Both women } \\
\text { we called were } \\
\text { booked that } \\
\text { weekend }\end{array}$ & $\begin{array}{l}\text { Both women } \\
\text { we booked } \\
\text { bailed at the } \\
\text { last minute }\end{array}$ & $\begin{array}{l}\text { All the } \\
\text { women were } \\
\text { probably busy }\end{array}$ & $\begin{array}{c}\text { Female } \\
\text { speakers are } \\
\text { always burnt } \\
\text { out from } \\
\text { speaking } \\
\text { so much }\end{array}$ & $\begin{array}{l}\text { Trying to get } \\
\text { more female } \\
\text { speakers } \\
\text { is sexist }\end{array}$ \\
\hline $\begin{array}{l}\text { The organisers } \\
\text { just wanted to } \\
\text { get the best } \\
\text { speakers they } \\
\text { could find }\end{array}$ & $\begin{array}{l}\text { You can't kick } \\
\text { out a male } \\
\text { speaker just } \\
\text { to fit a woman } \\
\text { in there }\end{array}$ & FREE & $\begin{array}{l}\text { You can't } \\
\text { shoehorn in } \\
\text { a woman } \\
\text { where she } \\
\text { doesn't fit }\end{array}$ & $\begin{array}{c}\text { Women never } \\
\text { volunteer to } \\
\text { present }\end{array}$ \\
\hline $\begin{array}{l}\text { You have to be } \\
\text { bold; people } \\
\text { aren't just } \\
\text { going to invite } \\
\text { you to present }\end{array}$ & $\begin{array}{l}\text { Woman } \\
\text { are shy }\end{array}$ & $\begin{array}{c}\text { Women only } \\
\text { ever want to } \\
\text { talk about } \\
\text { woman-stuff }\end{array}$ & $\begin{array}{l}\text { Women } \\
\text { need to act } \\
\text { more like } \\
\text { men }\end{array}$ & $\begin{array}{l}\text { No one has } \\
\text { complained } \\
\text { about } \\
\text { this before }\end{array}$ \\
\hline $\begin{array}{c}\text { Attendees } \\
\text { want to hear } \\
\text { from people } \\
\text { like themselves }\end{array}$ & $\begin{array}{l}\text { Well, there } \\
\text { aren't that } \\
\text { many female } \\
\text { attendees } \\
\text { either }\end{array}$ & $\begin{array}{l}\text { We're only } \\
\text { responding to } \\
\text { demand }\end{array}$ & $\begin{array}{c}\text { Fine, YOU tell } \\
\text { me who they } \\
\text { should have } \\
\text { invited. }\end{array}$ & $\begin{array}{l}\text { Who? I've } \\
\text { never heard } \\
\text { of her }\end{array}$ \\
\hline
\end{tabular}

Female Conference Speaker Bingo: Because making excuses is way easier than making progress. Source: Caperton (2012), http://www.feministe.us/blog/ archives/2012/og/24/why-arent-there-more-women-at-stem-conferences-thistime-its-statistical/ 